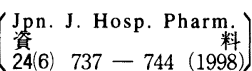

\author{
改良型フェニトイン製剤に変更した患者における \\ 投与量と血中濃度に関する検討 \\ 一変更時に投与量を減量後, 維持可能であった症例と \\ 増量を必要とした症例の比較一
}

小嶋文良*，豊口禎子，仲川義人

山形大学医学部附属病院薬剛部

\title{
The Investigation of Oral Doses and Serum Concentrations in Patients \\ Switched to an Improved Preparation of Phenytoin \\ - Comparison between the Patients Kept on Reduced Doses of the New \\ Preparation and the Patients who Required Additional \\ Doses after a Reduction during Exchange-
}

\author{
FUMIYOSHI OJIMA*, TEIKO TOYOGUCHI and YOSHITO NAKAGAWA \\ Department of Pharmacy, Yamagata University Hospital $\dagger$
}

$\left(\begin{array}{l}\text { Received January 8, } 1998 \\ \text { Accepted June 10, } 1998\end{array}\right)$

Phenytoin (PHT), an anticonvulsant drug, has been reported to have different absorbing dispositions caused by differences in its preparation. With PHT there is a risk that toxic effects may appear after changing to improved absorbing preparations because of its narrow therapeutic range in the serum concentration. As a result, it is necessary to determine the appropriate prescription dose based on the serum PHT concentration and symptoms of the individual patients. In order to investigate the prescription dose of PHT during the exchange from PHT 10\% powder (PHT 10) prepared in our hospital to ALEVIATIN ${ }^{\circledR} 10 \%$ Powder (ALV 10, Dainihon Seiyaku) which is reported to have improved absorption characteristics, we investigated the serum PHT concentrations, the doses of PHT 10 and ALV 10, and the symptoms of the patients before and after the change in the PHT preparations.

The mean serum PHT concentration and the mean serum PHT concentrations to the oral doses ratio (S/D ratio) with ALV 10 in the patients prescribed the same dose $(n=11)$ during the exchange of preparations were $7.62(\mu \mathrm{g} / \mathrm{mL})$ and $1.69(\mu \mathrm{g} / \mathrm{mL}) /(\mathrm{mg} / \mathrm{kg} /$ day $)$, respectively, and were larger (but not significantly so) than those of PHT 10 (4.84 and 1.06, respectively). In the 21 patients receiving the reduced doses of ALV 10, the mean serum PHT concentrations treated by ALV 10 were 7.16 and were the same as those of PHT 10, however, the mean S/D ratio of ALV 10 was 1.91 and increased (not significantly) in comparison with those of PHT 10 (1.58). In the 21 patients receiving the reduced doses of ALV 10, the oral doses and the reduction rates during the change from PHT 10 to ALV 10 were the same between the patients that kept the reduced doses $(n=12)$ and the patients required to have additional doses of ALV $10(n=9)$ after a reduction of ALV 10 treatment during the change in preparations. In the patients requiring addi- 
tional doses of ALV 10 after using the lower doses of ALV 10, the mean serum PHT concentration and S/D ratio for PHT 10 were 4.17 and 0.87 , respectively, which were significantly lower than those in the patients who could be kept on the reduced doses of ALV 10 (9.39 and 2.11, respectively). The mean serum PHT concentratios and S/D ratio in the ALV 10 were 3.97 and 1.15 , respectively, which were significantly lower than those of patients who were able to stay on the reduced dose of ALV 10 (9,56 and 2.48, respectively).

When switching to the improved absorbing PHT preparations, usually the same dose should be prescribed as the PHT 10 because of the risk that a uniform reduction in the doses according to the conversion table might cause seizures especially in the patients with low serum PHT concentrations for the lower absorbing PHT preparations.

Key words - absorption, ALEVIATIN ${ }^{\circledR} 10 \%$ Powder, oral dose of phenytoin, phenytoin $10 \%$ powder, serum phenytoin concentration

\section{緒言}

抗てんかん薬であるフェニトイン（PHT）は有 効血中濃度範囲が狭く，投与量と血中濃度の関係 が非線形で表され，僅かな投与量の変動が血中濃 度に大きく影響し，効果が減弱したり，中毒症状 が発現しやすい薬物である11. また凬形によって 吸収が異なることが報告2-4)されており，賦形剤 や剤形を変更したことによって中毒が発現した例 も認められている ${ }^{4,5)}$. 当院でもフェニトイン末 （アレビアチン，大日本製薬(株)）を原料とした 10 倍散（PHT10）を院内製犁として調製していた が，厚生省薬務局，医薬品再評価結果 ${ }^{3)}$ に基づ き，吸収性が改良された10倍散（アレビアチン10 倍散，大日本製薬(㑣)，ALV10）への切り替えを 行った。その際，急激な血中濃度の変化にともな う薬効および副作用への影響を十分に考慮した投 与量の減量を行う必要がある ${ }^{6-10)}$ 。当院では製剤 変更時の減量方法の報告6-10) より, Yukawa ${ }^{7)}$ ，末 松 ${ }^{9)}$ らの吸収率の予測を基にした大日本製薬(株)提 供の換算表を一部修正し，全診療科ならびに全処 方医にその情報を配布するとともに，口頭と電子 メールにて情報提供の徹底に努めた。しかし， PHT は先に述べたように, 投与量と血中濃度の 関係が非線形で表されるのみならず，個人によっ

$\dagger$ 山形市飯田西2-2-2;2-2-2, Iida-Nishi, Yamagata, 990-9585 Japan
て変動が大きいため ${ }^{1)}$ ，投与量を減じても副作用 が発現する可能性や，用量不足により症状が悪化 した例も報告されている ${ }^{8)}$. 当院でも今回の製剤 変更に伴い, 投与量の減量を行った症例の中で, その後, ALV10の増量が必要となった症例が認 められた。そこで，今回の変更に伴って行われた PHTの処方量と血中濃度の変化, 加えてその後 の処方量の変更の有無と血中濃度について調査を 行うとともに，減量後に，そのまま維持できた症 例と増量を必要とした症例の比較を行い, PHT の製䬉変更時の注意点について考察を行った.

\section{材料および方法}

\section{PHT 製剤}

変更以前の $10 \%$ フニトイン末 (PHT10)：ア レビアチン原末（大日本製薬）を 42 メッシュで節 下後，分散性を向上させるため，結晶乳糖と粉末 乳糖（4:1）の混合物 ${ }^{11)}$ を賦形片として, 混 合機（メリックス混合機，TOSHO）で15分間擋 拌混合し，10\%の院内製剤として調製した。

変更後のアレビアチン10倍散（ALV10）：平成 9 年 1 月に発売された大日本製薬(侏)のアレビアチ ン10倍散を新規採用し，換算表を参考に，処方量 は医師の判断にて決定した。

換算表：入手した換算表には換算前の量が PHT の重量として「mg」で表記されており，換 算後は10倍散全体の重量として「mg」単位で表記 
されており，まぎらわしいものである，そのた め, すべて PHT 原末の処方量として, 単位を $\lceil\mathrm{mg} 」 て ゙$ 統一するとともに, 間い合わせ先等の情 報を付加して各医師に配布した。

\section{2. 調査対象および方法}

院内製荗のPHT10からALV10へ切り替えた 1997年 6 月16日の前後 3 力月, すなわち1997年 3 月より10月までの PHT 処方患者を対象に, 変更 前後の処方内容と血中濃度測定結果, ならびにそ の後の症状発現の有無について調査を行った. 製 剤変更前後に継続して処方されていた患者は68名 であった (Table 1). 平均年齢は38.6歳, 他の 抗てんかん薬の併用薬については Table 2 に示す
とおり, PHT 単独が 44 名, 1 剂併用が 14 名, 2 片併用が 8 名, 3 郕以上の併用例が 2 名であっ た。疾患はてんかんの患者が31名, 脳腫瘍等の術 後の患者が37名であった。この中で変更後増量を 要した 2 名はPHTの投与量を設定する過程にあ り，血中濃度が測定されていたものの不安定期の 状態であったため今回は検討対象から除外した. 剤形変更により，投与量に変更のなかった患者は 24名であり, 減量された患者は42名であった。

3. 血清中フェニトインの測定

PHT10服用開始から 2 週間以上経過後, また ALV10への変更後 2 週間以上経過し, 定常状態 に達した患者を対象に, 服用から $3-9$ 時間後に

Table 1. Patient Information of those Prescribed PHT during the Exchange of Preparations

\begin{tabular}{lccccccc}
\hline $\begin{array}{c}\text { Reduced } \\
\text { Dose }\end{array}$ & $\begin{array}{c}\text { Same } \\
\text { Dose }\end{array}$ & $\begin{array}{c}\text { Increased } \\
\text { Dose }\end{array}$ & Total & & n & Mean Age (SD) \\
\hline Inpatients & 9 & 4 & 0 & 13 & Male & 37 & $43.5(20.0)$ \\
Outpatients & 33 & 20 & 2 & 55 & Female & 31 & $34.4(21.0)$ \\
\hline Total & 42 & 24 & 2 & 68 & & 68 & $38.6(20.9)$ \\
\hline
\end{tabular}

Table 2. Combination of other Anticonvulsion Drugs with PHT

\begin{tabular}{lc}
\hline Anticonvulsion Drugs & n \\
\hline PHT alone & 44 \\
PHT+VPA & 3 \\
PHT+ZNS & 8 \\
PHT+PB & 2 \\
PHT+CZP & 1 \\
PHT+VPA+ZNS & 4 \\
PHT+PB+CBZ & 1 \\
PHT+PB+VPA & 2 \\
PHT+CBZ+VPA & 1 \\
PHT+CBZ+VPA+CZP & 1 \\
PHT+CBZ+VPA+CZP+PRM & 1 \\
\hline
\end{tabular}

CBZ: Carbamazepine, CZP: Clonazepam, PB: Phenobarbital, PHT: Phenytoin, PRM: Primidone, VPA: Valpronic Acid, ZNS: Zonisamide 
採血した。血液は $1,500 \times \mathrm{g}, 10$ 分間遠心し, 得ら れた血清を検体とし，採血当日に蛍光偏光免疫法 （TDX-FLX，ダイナボット）にて血清中 PHT 濃 度を測定した。

\section{4. 解析}

データは平均值士標準偏差で表した。 有意差検 定は剤形変更前後における同一患者での比較は対 応のある $\mathrm{t}$ 検定で行い, それ以外の 2 群間の比較 は対応のない $\mathrm{t}$ 検定を用いて行った． 3 群以上の 比較は分散分析を行い, 群間の比較は Scheffeの 多重比較検定を用い，それぞれ危険率 0.05 以下の 場合を有意差ありと判定した。

\section{結果}

\section{1. 製剤変更による投与量の未変更症例と減量症 例の比較}

製剤変更の前後で，投与量の変更がなく，継続 して血中濃度を測定していた症例は11例であった (未変更群)。未変更群と, 減量した 21 症例（減量 群）のPHT10とALV10の 1 日あたりの投与量, 血中濃度, 血中濃度と投与量の比（S/D 比）を Table 3 に示した。二群間における投与量は, 変 更前ばかりでなく変更後, および減量群の前と後
における比較でも有意な差は認められなかった. 未変更群の血中濃度はALV10に切り替えること

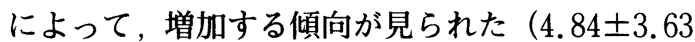
$\rightarrow 7.62 \pm 5.72 \mu \mathrm{g} / \mathrm{ml})$ が，有意差は認められなか った. 減量群においても PHT10とALV10投与時 の血中濃度には差が認められなかった(7.16士 $4.81 \rightarrow 7.16 \pm 4.90 \mu \mathrm{g} / \mathrm{ml})$ 。また, PHT10服用時 の血中濃度は, 減量群 $(7.16 \pm 4.84 \mu \mathrm{g} / \mathrm{ml})$ に比 し, 未変更群が低值 $(4.81 \pm 3.63 \mu \mathrm{g} / \mathrm{ml})$ の傾向 は示したものの, 有意差は認められなかった. 更 に S/D 比は未変更群, ならびに減量群のいずれ も, PHT10投与時に対して, ALV10投与に変更後 に増加する傾向は認められたが，有意なものでは なかった。

2. 製剤変更時に滅量後，投与量が維持できた症 例と増量を必要とした症例の比較

減量群の中でその投与量で維持可能であった症 例（減量維持群）と増量を必要とした症例（増量 必要群) に分けて, 血中濃度, 投与量等の比較検 討を行った. Table 3 の減量群21症例の中で, 減 量維持群は12症例であり, 増量必要群は 9 症例で あった。増量必要群 9 例の中で, 症状の憎悪が認 められた症例は 5 例，明確な症状の悪化は認めら

Table 3. PHT Dose $(\mathrm{mg} / \mathrm{kg} / \mathrm{day})$, Seruem PHT Concentration $(\mu \mathrm{g} / \mathrm{ml})$ and S/D Ratio of PHT 10 and ALV 10 in the Patients with or without a Dose Reduction during the Change in Preparations

\begin{tabular}{|c|c|c|c|}
\hline $\begin{array}{l}\text { Prescribed Dose of PHT during } \\
\text { the Exchange of Formulations }\end{array}$ & $\mathbf{n}$ & PHT10 & ALV10 \\
\hline \multicolumn{4}{|l|}{ PHT Dose (mg/kg/day) } \\
\hline $\begin{array}{l}\text { No Change } \\
\text { Reduced }\end{array}$ & 11 & $\begin{array}{l}4.56 \pm 1.62- \\
5.05 \pm 1.99-\end{array}$ & $\begin{array}{r}4.56 \pm 1.62-\text { i } \\
- \text { N.S. }\end{array}$ \\
\hline \multicolumn{4}{|l|}{ Serum PHT Concentration $(\mu \mathrm{g} / \mathrm{mL})$} \\
\hline $\begin{array}{l}\text { No Change } \\
\text { Reduced }\end{array}$ & $\begin{array}{l}11 \\
21\end{array}$ & $\begin{array}{l}\mathbf{4 . 8 4} \pm \mathbf{3 . 6 3}-\text { । } \\
\mathbf{7 . 1 6} \pm \mathbf{4 . 8 1}-^{\text {N.S. }}\end{array}$ & 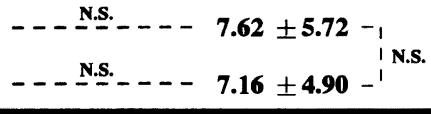 \\
\hline \multicolumn{4}{|l|}{$\mathrm{S} / \mathrm{D}$ ratio $(\boldsymbol{\mu g} / \mathbf{m L}) /(\mathbf{m g} / \mathbf{k g} /$ day $)$} \\
\hline $\begin{array}{c}\text { No Change } \\
\text { Reduced }\end{array}$ & 11 & $\begin{array}{l}1.06 \pm 0.68-\text { i } \\
1.58 \pm 1.29-\text { N.s. }\end{array}$ & $\begin{array}{c}- \text { N.S. }_{-}--1.69 \pm 1.22-\text { i N.S. } \\
-\ldots \text { N.S. } \\
\end{array}$ \\
\hline
\end{tabular}


れないが，血中濃度が低いため医師の判断で増量 した症例は 2 例, 残り 2 例については転院先の病 院で增量しており，正確な理由は不明であった。

減量維持群と増量必要群の投与量, 血中濃度, S/D 比を Fig. 1，2，および Table 4 に示した. 投与量が減量されているにもかかわらず，二群い ずれも PHT10投与時と ALV10変更後の間におけ る平均血中濃度, S/D 比には差が認められなか った。しかし, 減量維持群と増量必要群との群間 比較では，PHT10投与時，およびALV10投与時 の血中濃度および $\mathrm{S} / \mathrm{D}$ 比の值に差が認められ（p $<0.05)$, 増量必要群における值が有意に小さか った.

\section{3. 減量維持群と増量必要群における減量割合の} 検討

製剤変更時の実際の減量割合と, 換算表より求
めた各患者の減量割合を Table 5 に示した。減量 維持群 (16.71士9.77\%) は増量必要群（21.86士 9.63\%) に比し, 減量割合が小さい傾向を示した が，両群間に有意な差は認めらなかった。一方， いずれの群も，換算表による減量割合（Table 5 , right）より実際の減量割合（Table 5 , left） が大きい傾向にあったが, 有意差を呈するほどで はなかった。

\section{考察}

「PHT（末）およびその10倍散の一部に吸収性 が低い製剤があり，他剤形と生物学的に同等性が 確保されるような製剤に切り替えることが望まし い」との医薬品再評価結果 ${ }^{3)}$ 受けて, 当院でも 院内製剤であったPHT10より, 新製品のアレビ アチン10倍散（ALV10)への切り替えを行った。

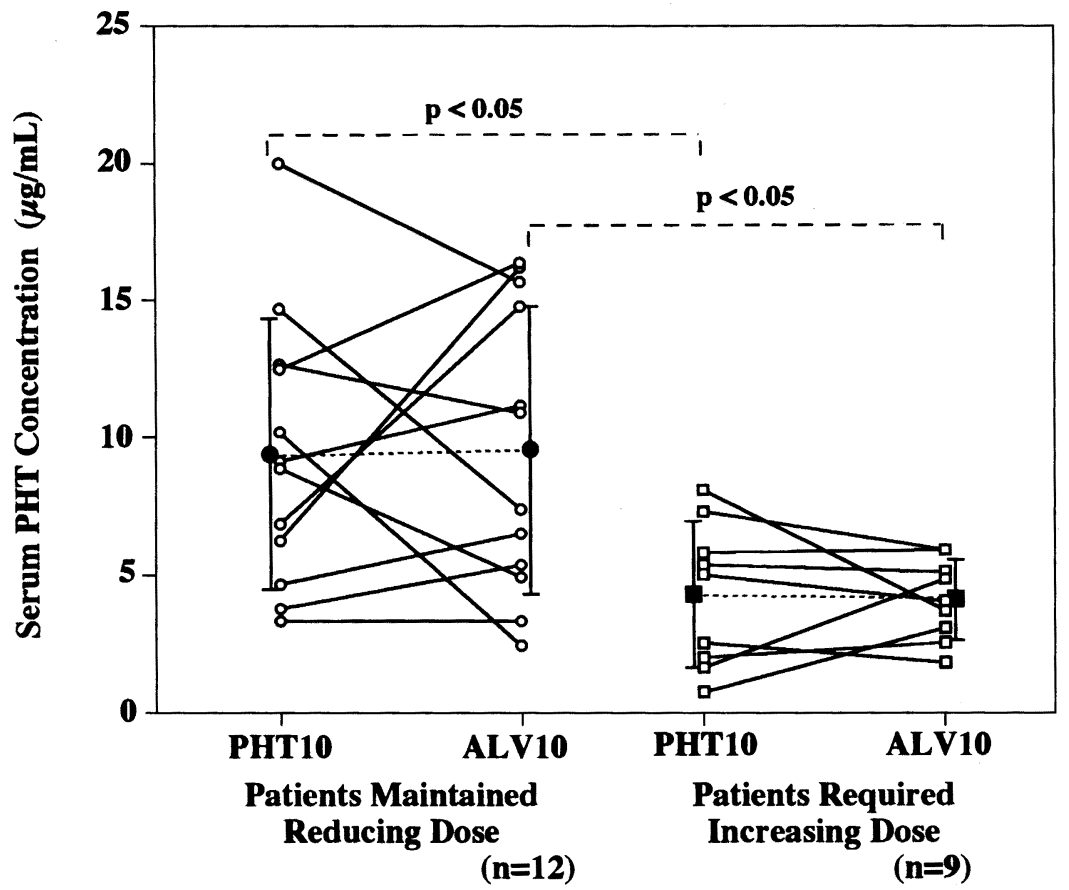

Fig. 1. Serum PHT Concentrations $(\mu \mathrm{g} / \mathrm{ml})$ of PHT 10 and ALV 10 in the Patients Maintained on Reduced Doses of ALV 10 and the Patients Required Increasing Doses of ALV 10 after Reduction of ALV 10 during the Change in Preparations.

Closed circles and squares, and Vertical Bars Reprsesent Means and Standard Deviations, respectively. 


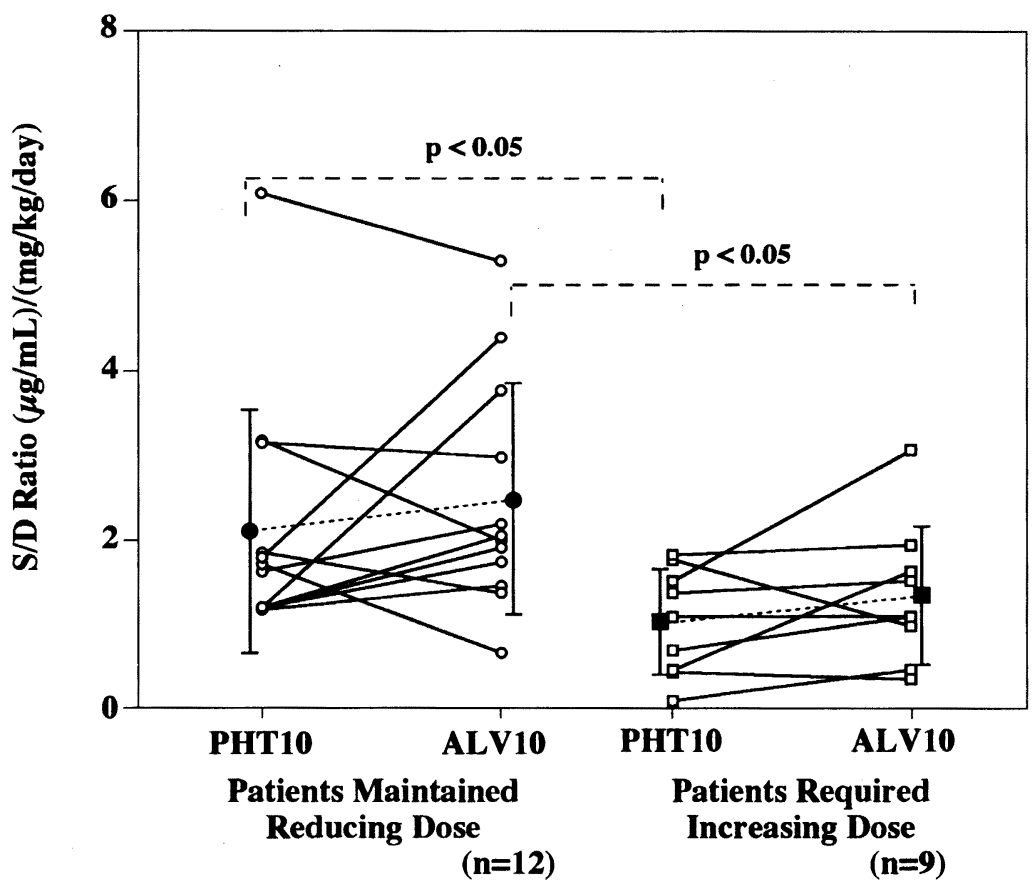

Fig. 2. Serum PHT Concentration to Dose Ratios (S/D Ratio) of PHT 10 and ALV 10 in the Patients Maintained on Reduced Doses of ALV 10 and the Patients Required Increased Doses of ALV 10 after Reduction of ALV 10 during the Change in Peparations. Closed Circles and Squares, and Vertical Bars Represent Means and Standard Deviation, respectively.

Table 4. PHT Dose (mg/kg/day), Serum PHT Concentration $(\mu \mathrm{g} / \mathrm{ml})$ of PHT and S/D Ratio of PHT 10 and ALV 10 in the Patients Maintained on Reeuced Doses of ALV 10 and the Patients Required Increased Doses of ALV 10 after Reduction of ALV 10 during the Change in Preparations

\begin{tabular}{|c|c|c|c|}
\hline $\begin{array}{c}\text { Prescribed Dose of PHT } \\
\text { after Reduction of ALV10 }\end{array}$ & $\mathbf{n}$ & PHT10 & ALV10 \\
\hline \multicolumn{4}{|l|}{ PHT Dose (mg/kg/day) } \\
\hline $\begin{array}{l}\text { Maintained } \\
\text { Required Increase }\end{array}$ & $\begin{array}{l}12 \\
9\end{array}$ & $\begin{array}{l}4.80 \pm 2.02-1,-- \text { N.S. } \\
5.38 \pm 2.00-1\end{array}$ & $\begin{array}{l}3.93 \pm 1.47-\text { i } \\
4.25 \pm 1.81-\text { N.s. }\end{array}$ \\
\hline \multicolumn{4}{|l|}{ Serum PHT Concentration $(\mu \mathrm{g} / \mathrm{mL})$} \\
\hline $\begin{array}{l}\text { Maintained } \\
\text { Required Increase }\end{array}$ & 12 & $\begin{array}{l:c}9.39 \pm 4.93- & -\ldots-\underline{N . S .} \ldots- \\
4.17 \pm 2.26- & P<0.05\end{array}$ & $\begin{array}{l}9.56 \pm 5.25-1 \\
3.97 \pm 1.44-1\end{array}$ \\
\hline \multicolumn{4}{|l|}{$\mathrm{S} / \mathrm{D}$ ratio $(\mu \mathrm{g} / \mathrm{mL}) /(\mathrm{mg} / \mathrm{kg} / \mathrm{day})$} \\
\hline $\begin{array}{c}\text { Maintained } \\
\text { Required Increase }\end{array}$ & 12 & 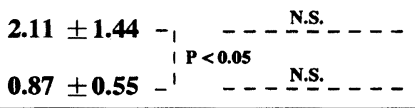 & $\begin{array}{l}2.48 \pm 1.36-1 \\
1.15 \pm 0.72-\end{array}$ \\
\hline
\end{tabular}


Table 5. Actual Reduction Rate (\%) and Reduction Rate (\%) Derived from the Conversion Table in the Patients Maintained on Reduced Doses of ALV 10 and the Patients Required Increased boses of ALV 10 after Reduction of ALV 10 during the Change in Preparatoins

\begin{tabular}{cccc}
\hline $\begin{array}{c}\text { Prescribed Dose of PHT } \\
\text { after Reduction of ALV10 }\end{array}$ & n & Actual Reduction Ratio (\%) & $\begin{array}{c}\text { Reduction Ratio (\%) Derived } \\
\text { from Conversion Table }\end{array}$ \\
\hline Maintained & 12 & $16.71 \pm 9.77-$ & N.s. \\
Required Increase & 9 & $21.86 \pm 11.29-$ & N.S. \\
\hline
\end{tabular}

PHT は代謝に飽和状態が存在し, Michelis-Menten の式に近似され，投与量と血中濃度の関係は曲線 で表される1,12).そのため，わずかな投与量の変 更や吸収性の違いが血中濃度に大きく影響し, 吸 収性の良いALV10へ切り替える際に，一定割合 での減量では症状のコントロールが困難な薬物で ある。

吸収性のよい製剤へ切り替える際の換算手段は これまでにも報告されている(6-10)が，血中濃度が 低下したり，効果が減弱して症状の悪化をきたす など, 必要条件を完全に満たしてはいない場合も ある ${ }^{8)}$. 当院での切り替え時にも減量後，そのま まの用量を維持できている症例もあったが, 発作 発現によって増量を余儀なくされた症例も認めら れた。これは換算表に従って減量することの危険 な症例が存在することを意味しており，その問題 点を明らかにする必要がある。そのため PHT 製 剤を変更する前後で血中濃度を測定していた症例 について，それぞれの投与量と血中濃度の比較， さらに症状発現の有無について検討を行った.

血中濃度に関しては, 投与量の未変更群におい てALV10に変更したことによって, PHT 血中濃 度は増加傾向を示した。また, ALV10への変更 時に投与量を減らした減量群でも血中濃度が PHT10投与時に比べて低下しておらず，院内製羭 (PHT10)に比し, ALV10の吸収性の良さが示唆さ れた. 未変更群ではPHTの血中濃度が增加して いる症例が多いわけであるが，逆に低下している 症例や, 減量群においても血中濃度が高くなって いる症例が認められ, 最終的な投与設計には, や
はり個々の患者における血中濃度測定が必要であ るといえよう.血中濃度と投与量の比である S/D 比でも同様のことが認められ, PHT10から ALV 10へ切り替える際には, 未変更群において平均血 中濃度ならびに S/D 比が約60\%増加しており，

PHT10に比較し, ALV10は吸収性が向上している ことが裏付けられた.

減量群の中で, その後症状悪化等の理由によっ て増量の必要が生じた増量必要群と減量維持群と の間では, PHT10使用時の投与量に差は認められ ず, 症状が安定していたことを考えると増量必要 群の投与量が少なかったわけではない. また減量 率の比較でも, 増量必要群の減量割合が大きい傾 向は示した（Table 5 ）ものの, 有意差は認めら れてはいない，変換表による減量割合と比較する と, 増量必要群において。実際の減量割合が大き い傾向があり, 増量を必要とした症例で過度の減 量を行ったために, 症状が悪化した症例も含まれ ている可能性は否定できないものの, 増量が必要 であったことの主な要因ではないと考えられる (Table 5 ).

今回の検討で減量維持群と増量必要群の間に有 意な差が認められたのは, 血中濃度ならびに S/D 比であり（Table 4, Fig. 1, 2)，いずれの結果 も PHT10投与時とALV10投与時の双方におい て, 増量必要群が低值を示した。これらの症例の ほとんどが PHT10投与時のそれと同じ投与量に 戻されており，本来は切り替え時に減量を必要と しなかった症例と考えられる。

PHT の吸収性が改善された製剤への変更に伴 
つて，薬剤部より医師に提示した換算表に準じた 減量法は, 減量維持群では変更前とほぼ同じ血中 濃度が得られており，製片変更によって中毒症状 を発現した症例は認められず, 多くの症例では妥 当な手段といえる。しかし，今回検討した症例の 中には換算表より求めた減量率より小さい減量率 だったにもかかわらず，その後増量を必要とした 症例も認められた。今回の結果からも吸収性の良 いALV10に切り替える際に，すべての患者に適 応できる換算表を作成することは困難であること が判明し, 改めて血中濃度測定の重要性と, 個々 の患者に適した投与量のきめ細かな投与設計が必 要であると考えられる。末松らの報告9)では吸収 性の悪い製剤の時点で $10 \mu \mathrm{g} / \mathrm{ml}$ 以下の血中濃度 の患者については等量変更を目安としても中毒症 状を発現した患者は認められていない。しかし， PHT のように治療域と毒性発現域の血中濃度が 近接している薬物では症状をコントロールできる 範囲で，可能な限り低い血中濃度に維持すべきで あり，吸収性の良い製㓮に切り替える際には， PHT10の時点で血中濃度が $10 \mu \mathrm{g} / \mathrm{ml}$ 以下の症例 でも減量を考慮すべき症例が存在する可能性が十 分考えられる，等量変更を考慮する必要のある症 例は吸収性の悪いPHT10の時点での血中濃度が $5 \mu \mathrm{g} / \mathrm{ml}$ 以下，もしくは S/D 比が 1 以下であり， 吸収が良いPHT 製片に切り替える際には元の投 与量をそのまま継続することも考慮する必要があ る。しかし，これらの数值に関しては減量維持可
能群と増量必要群との間でオーバーラップしてい る部分があり，最適策としては個々の患者の血中 濃度や症状に応じた投与設計を行うことの重要性 が改めて結論づけられた結果となった。

\section{引用文献}

1) J. K. Aronson, M. Hardman and D.J.M.Reynold, B.M.J., 305, 1215-1218 (1992).

2) 名倉益男，神経内科，12，287-291 (1980).

3) 医療用医菜品再評価結果平成8年度 (その1)。薬 発第573号厚生省薬務局通知，2．フェニト1 ン, (1996).

4) J.H. Tyrer, M.J. Eadie, J.M. Sutherland and W.D.Hooper, B.M.J. 31, 271-273 (1970).

5) 西原カズヨ, 幸田幸直, 斎藤侑也, 小森貞嘉, 田中茂，高須俊明，神経内科，10，452-456 (1979).

6）名倉益男，河合逸雄，精神神経薬理， 4, 187192 (1982)

7) E.Yukawa, S.Higuchi and T.Aoyama, Chem. Pharm. Bull., 38, 1973-1976 (1990).

8）武藤福保, 谷内弘道, 鎌田準輔, 市村明彦, 直 江裕之, 松本三樹, 千葉茂, 宮岸勉, 精神医学 37, 639-644 (1995).

9）末松文博，原口国高，入江刊行，村上宅司，宮 崎正一, 江藤清二, 佐々木俊行, 九州薬学会会 報 49, 61-67 (1995).

10）小坂好男，有馬貴子，高橋美香，菊池有道，藤 田武久, 橋本清, TDM 研究，X，3，292-293 (1993).

11）丹野慶紀, 佐々木吉幸, 薬学雑誌, 94, 221-224 (1974).

12）高田寛治, “薬物動態学,一基礎と応用一”，5章 6非線形薬物動態学, 薬業時報社, 東京, 1987, pp.122-133. 